\title{
Intellectual role of civil property protection in the world experience of law enforcement and legislation
}

\author{
Jumanazar KHOLMUMINOV1', Farhod KHOLIQNAZAROV²
}

Termez State University

\begin{tabular}{l} 
ARTICLE INFO \\
\hline Article history: \\
Received October 2021 \\
Received in revised form \\
15 October 2021 \\
Accepted 15 November 2021 \\
Available online \\
25 December 2021
\end{tabular}

\section{Keywords:}

Intellectual property, industrial property,inventions, popular brands, creative copyright, legal norms.

\begin{abstract}
Intellectual property right is an intellectual (intellectual) right that belongs to the result of the activity of the initiator of the actions of the rights holder or owner. The owner has the right to the absolute legal use of such property, at his discretion, in any form and in any way. The use of such property objects belonging to the right holder on the basis of absolute right is allowed only with the consent of the rights holder or the owner.

2181-1415/C 2021 in Science LLC.

DOI: https://doi.org/10.47689/2181-1415-vol2-iss11/S-pp103-107

This is an open access article under the Attribution 4.0 International (CC BY 4.0) license (https://creativecommons.org/licenses/by/4.0/deed.ru)
\end{abstract}

\section{Интеллектуал мулк хуқуқини химоя қилишнинг жахон тажрибасидаги ўрни}

\footnotetext{
Калит сўзлар:

интеллектуал мулк,

саноат мулки,

ихтиролар,

машхур брендлар,

ижодий муаллифлик

хукуқи,

хуқуқий нормалар.
}

\section{АННОТАЦИЯ}

Интеллектуал мулк хуқуқи - интеллектуал (ақлий) фаолият натижасига тегишли хуқуқ. Мулк эгаси ана шу интеллектуал мулк объектларидан ўз хохишига кўра, хар қандай шаклда ва хар қандай усулда мутлақ қонуний фойдаланиш хуқуқига эгадир. Хуқуқ эгасига мутлақ хуқуқ асосида тегишли бўлган интеллектуал мулк объектларидан бошқа шахсларнинг фойдаланишига фақат хуқуқ эгасининг розилиги билангина йўл қўйилади.

\footnotetext{
${ }^{1}$ Termez state University, Faculty of Law, dean, doctor of jurisprudence, professor. Termez, Uzbekistan.

2 Termez State University, Law Faculty, Direction of Jurisprudence, 2nd year student. Termez, Uzbekistan.
} 


\section{Интеллектуальная роль защиты гражданской собственности в мировом опыте правоприменения и законодательства}

\begin{tabular}{l}
\hline Ключевые слова: \\
интеллектуальная \\
собственность, \\
промышленная \\
собственность, \\
изобретения, \\
популярные бренды, \\
авторское право на \\
творчество, \\
правовые нормы.
\end{tabular}

АННОТАЦИЯ

Право интеллектуальной собственности -
интеллектуальное (интеллектуальное) право, принадлежит результату деятельности инициатору действий правообладателя или собственника. Владелец имеет право, на абсолютное законное использование таких объектов собственности, по своему усмотрению, в любой форме и любым способом. Использование таких объектов собственности, принадлежащих правообладателю на основании абсолютного права, допускается только с согласия правообладателя или собственника.

Intellectual property is a product of creative intellectual activity. Other types of creative activity in the field of science, literature, art and production, literary, artistic, scientific works, radio, television works, discoveries, inventions, industrial designs, computer programs, databases, trademarks, included in the set of inventions and copyright, firm terms and other intellectual property. At present, the protection of intellectual property is an important task. The Republic of Uzbekistan became a member of the World Intellectual Property Organization in December 1991, and in 1993 joined the Paris Convention for the Protection of Industrial Property.

President of the Republic of Uzbekistan Sh. Mirziyoyev held a meeting on October 12, 2021 to discuss measures to improve the system of protection of intellectual property, noting the following: creation of a database of intellectual property of their countries; last year about 400 inventions, 110 utility models, Although 170 industrial designs and 36 selection achievements have been registered, only 43 scientific developments have been commercialized. Therefore, it is necessary to organize an "electronic fair" of such scientific achievements."

This is due to the fact that the issue of copyright infringement is becoming a topical issue not only in Uzbekistan but around the world. First, it's an easy way to make a profit or even extra profit without having to spend to create something new. Second, modern technology has made the process of data reproduction and distribution extremely easy and inexpensive. In the past, authors and legitimate producers had natural protection. These were: the complexity of the technique, the complexity of the process, and the high cost of the copy obtained. So far, a lot has developed. Including: computers and typewriters, copies can be cheap, and sales can be expensive - so there are additional benefits. Many scientists around the world have done scientific and practical work to prevent these problems. Former Director General of the World Intellectual Property Organization: Hendrik Christian Bodenhausen (Netherlands, 1970-1973), Arpad Bogsh (Hungary, 1973-1997), Kamil Idris (Sudan, 1997-2008), and management from 2008 to present. Francis Gaarry and others have written a number of works on intellectual property rights while working as executives. There are also scholars in Uzbekistan who have done works and practical work on intellectual property rights. In particular: Director of the State Patent Office of the Republic of Uzbekistan Akil Adilovich Azimov (since 1992). Under the leadership of Azimov, work was carried out to establish and develop a state system of legal protection and use of intellectual property. 
Saidmalik Azimov Akbarovich, a member of the Scientific Methodological Council of Defectology at the Republican Center for Education, is also the author of many scientific papers on intellectual property rights.

We can see that Doctor of Law, Professor O. Okyulov has conducted research in this area and raised these issues several times in his works. One of such views is that in their work intellectual property can be the subject of collateral, noting that any exclusive rights and intellectual property rights on intellectual property can be pledged, as well as the process is not applied in our country. Noting that this process is very well organized in foreign countries, they also gave insights on how to carry out this stage. In other words, they explained that if a loan is obtained on the security of intellectual property, the bank must first examine it, and only if the object is found to have a promising and commercial value, the bank will provide the necessary loans through a mortgage agreement.

Another scientist in the field, 0 . Pakhomenko did not deny the advantages of this type of collateral, noting that the use of exclusive rights to an object of intellectual property as collateral has the following disadvantages: the object of intellectual property is a less liquid commodity, the scope of such objects is limited; in the case of many intellectual property rights pledged, but in the event of non-performance of obligations, the recovery may be directed to the pledged property in case of non-performance or inadequate performance by the debtor of the obligation secured by the pledge.

Another industry expert, S.I. Pirdanov, on the other hand, cannot fully protect the rights of the mortgagor due to the complexity of the procedure for mortgaging exclusive rights to copyright. In case of non-fulfillment of the pledge obligations, the commercialization of the exclusive rights to the pledge will depend on the will of the author of the object. In addition, in the event of the author's death, there is a serious possibility of litigation with the author's heirs over the commercialization of the mortgaged property rights, which suggests that copyright cannot be a reliable way to secure a bank loan obligation.

Effective use of human capital in developed countries, the widespread introduction of created intellectual property in the process of commercialization, the transformation of intellectual property into one of the most developed sectors of the economy are important indicators of economic development. For example, a single brand successfully used in product packaging is able to represent the image of a large company, or even the entire state. Popular brands such as Nike, Adidas, Apple, Mercedes Benz, Toyota are clear examples of this.

We must prioritize the following tasks in achieving these goals. First, to establish a special regime of use of mental labor products; second, the recognition of authorship for the result of intellectual activity; third, moral and material incentives; fourth, to protect the interests of copyrighted authors, employers, and others. The main purpose of such tasks is to develop the field of intellectual property rights now and in the future.

The object of intellectual property is a process that occurs as a result of the intellectual labor of the subject of intellectual property. Intellectual property objects vary depending on how they are a product of activity, forms and characteristics. For example: 1. According to the results of intellectual activity: works of science, literature, art; phonograms of performances of musical organizations; inventions, industrial products; production secrets. 2. Means reflecting the specific features of goods, works and services (company names, marks; appellation of origin, etc.). 
According to experts, security activities in relation to intellectual property imply the priority activities of the legislative structures of the government, the issuance of legal acts aimed at ensuring the observance of the legal rights of authors of creative products. In turn, the protection of rights includes the activities of the executive and judicial structures in the form of measures in response to violations of existing law. Although many lawyers categorize these two types of activities prefer to combine. I will now try to show you in detail what mechanisms exist for the protection of intellectual property rights in Russia. One of the main legal documents on the protection of copyright in Russia is the Law of the Russian Federation No. 5351 of 1993. According to the law, the field of intellectual property in Russia is highly dependent on judicial practice. That is, what is stated in normative acts usually requires additional interpretation in the process of implementing the appropriate type of hearing. Lawyers emphasize that the main thing is novelty and originality. That is, if the court was able to prove by the court that he had written the book for the first time, he recognized his right to defend the product of his labor.

Intellectual property accounts for 45 percent of GDP in Europe, 12 percent in China, and 7 percent in Russia.

About 4,500 intellectual property objects, including more than 2,000 trademarks, are registered in the country annually. For example, Navoi Mining and Metallurgical Combine has registered 35 inventions over the past decade, 16 of which have generated more than 400 billion soums in economic benefits. Negotiations are underway to sell these developments to gold mining companies in other countries.

Violations of the law in the field of intellectual property can also occur. I will now try to illustrate the example of the Republic of Uzbekistan. In particular, last year in the Republic of Karakalpakstan, regions and the city of Tashkent, in cooperation with the local working group on compliance with intellectual property legislation, 22 sales of counterfeit phonograms and audiovisual products were monitored in populated areas, markets, shopping malls and outlets. A total of 394 violations were identified and reports of violations were sent to the State Tax Committee and the Ministry of Internal Affairs. During the reporting period, 14,279 (12,059 counterfeit) audiovisual products, phonograms and electronic calculations were submitted to the Ministry of Internal Affairs and the State Tax Administration, 50 expert opinions were given on the programs created for the machines.

In recent years, in cooperation with the Global Innovation Index Group, our country has done a lot to ensure transparency and improve the criteria for evaluating innovative activities. These efforts have paid off, and today, in 2020, Uzbekistan ranked 93rd. Compared to the 122 nd place in 2015 , this can be called a huge increase. In addition, our country ranks 4th among Central and South Asian countries. This means that changes in the field of intellectual property are taking place in Uzbekistan, albeit slowly.

Among the results of human activity, the results of creative activity have a special place, firstly, inventions and works of science, literature and art, as well as industrial designs, topologies of integrated circuits, selection achievements and others. The level of creative activity outcomes can vary significantly. Therefore, the results of intellectual activity combine conceptual activity at any level. For a long time, the results of intellectual creative activity were not someone else's property, i.e., in modern terms, they were public property. In other words, any results of intellectual activity could be used by others without any restriction, although in many countries the authorship of the results of creative activity is recognized. Possession of the results of creative activity began to be 
recognized from the XV century. The Republic of Venice, the world's largest naval and commercial power, was one of the first to commercialize the results of creative activity. In other words, they began to recognize property rights as the result of creative activity. Later, such property was established in other countries. Gradually, the intellectual property system emerged.

The result of intellectual activity is understood not as a material object, but as the creative thought itself, that is, as an ideal, intangible object. Modern law radically refrains from interfering in the inner life of the individual, as well as from entering the realm of intimate relations between people: the law is not only with the outside world, but also with the soul engaged. If an opinion is not expressed, it does not exist for the law. You can't force a person to think, to create. You can only create such conditions that there is an opportunity for thinking, creativity. Without certain conditions, such an opportunity will not arise. But the creative process itself always falls outside the scope of legal norms. However, when the creative process ends with a production act, the norms of civil law come into force, regardless of its objective form, which ensures its public recognition, the regime of the legally relevant object and the protection of the rights and legitimate interests of its creator. The results of intellectual activity can only be the object of a legal relationship if they are dressed in any objective form that ensures that they are perceived by other people.

In conclusion, the idea of doing business in foreign countries by borrowing money from intellectual property is a very good idea, I think. However, the fact that these processes are still being tested in the experience of most countries is due to the fact that there is a risk of this process for some time. However, based on the experience of developed countries, if we continue to think, the effective use of promising intellectual property by lending will lead to the growth of entrepreneurial activity. Otherwise, the bank will be able to sell promising intellectual property in the process of debt collection without reducing their value at auction. That is, since there is a greater chance of finding a buyer, both parties may not be afraid in the future. In this regard, taking into account the existence of different views in our country, I considered it appropriate to propose the establishment of organizations that assess intellectual property in our country, and if their activities were under state control, it would accelerate the implementation of this process in our country. We need to contribute to the development of the whole world by responding to the opportunities that students create today.

\section{REFERENCES:}

1. Resolution of the President of the Republic of Uzbekistan on Intellectual Property.

2. Civil Code of the Russian Federation.

3. The Constitution of the Republic of Uzbekistan. Tashkent - "Uzbekistan" - 2019.

4. Teacher of Intellectual Property Protection: Senior Lecturer Sokolova Alyona Gennadyevna's report on "Principles of protection of intellectual property rights. Objectives and principles of legal protection of intellectual property".

5. From the speeches at the conference of the World Intellectual Property Organization on October 16-17, 2020 in Moscow, Russian Federation. 